\title{
OVER 16,000 YEARS OF FIRE FREQUENCY DETERMINED FROM AMS RADIOCARBON DATING OF SOIL CHARCOAL IN AN ALLUVIAL FAN AT BEAR FLAT, NORTHEASTERN BRITISH COLUMBIA
}

\author{
A J Timothy Jull \\ University of Arizona, NSF Arizona AMS Laboratory, P.O. Box 210081, Tucson, Arizona 85721, USA. \\ Email: jull@email.arizona.edu. \\ Marten Geertsema \\ British Columbia Forest Service, 1011 4th Avenue, Prince George, British Columbia, Canada V2L 3H9. \\ Email: marten.geertsema@gov.bc.ca.
}

\begin{abstract}
We present results of radiocarbon dating of charcoal from paleosols and buried charcoal horizons in a unique sequence, which potentially records the last $36,000 \mathrm{yr}$, from a fan at Bear Flat, British Columbia (BC) $\left(56^{\circ} 16^{\prime} 51^{\prime \prime} \mathrm{N}\right.$, $\left.121^{\circ} 13^{\prime} 39^{\prime \prime} \mathrm{W}\right)$. Evidence for forest-fire charcoal is found over the last $13,500 \pm 110^{14} \mathrm{C}$ yr before present (BP) or $16,250 \pm$ $700 \mathrm{cal} \mathrm{BP}$. The study area is located east of the Rocky Mountains in an area that was ice-free at least 13,970 $\pm 170{ }^{14} \mathrm{C} \mathrm{yr}$ BP $(17,450-16,150$ cal BP) ago. The latest evidence of fire is during the Medieval Warm Period (MWP). The charcoal ages show a periodicity in large fires on a millennial scale through the Holocene - an average of 4 fires per thousand years. Higher fire frequencies are observed between 2200 to $2800 \mathrm{cal} \mathrm{BP}, 2500$ and $\sim 6000 \mathrm{cal} \mathrm{BP}, \sim 7500$ to $8200 \mathrm{cal} \mathrm{BP}$, and 9000 to $10,000 \mathrm{cal}$ BP. These intervals also appear to be times of above-average aggradation of the fan. We conclude that fire frequency is related to large-scale climatic events on a millennial time scale.
\end{abstract}

\section{INTRODUCTION}

The long-term record of forest-fire history has been studied in a number of regions (Meyer et al. 1995, 2001; Cwynar 1987; Long et al. 1998; Hallett et al. 2003a,b; Millspaugh et al. 2000; Horn and Sanford 1992; Turcq et al. 1998; Lertzman et al. 2002; Hallett and Walker 2000; Pierce et al. 2004) of the world, but there is little information on fire history in more northerly regions of Canada. There are basically 2 kinds of studies: 1) direct measurement of charcoal found in alluvial and colluvial deposits (e.g. Meyer et al. 1995, 2001; Lertzman et al. 2002; Pierce et al. 2004); and 2) studies of the charcoal record found in lake sediments (e.g. Long et al. 1998; Millspaugh et al. 2000). In southern British Columbia (BC), there have been several studies (Hallett et al. 2003a,b; Lertzman et al. 2002) of fire histories in hemlock rainforests of the Fraser Valley, southwestern BC. Hallet and Walker (2000) studied fire from charcoal recovered from a lake in Kootenay National Park (southeastern BC), and Gavin (2003a) has studied fires in west-coast temperate rain forests on Vancouver Island. Sanborn et al. (2006) have studied fires from soil charcoal in an interior rain forest in east-central $\mathrm{BC}$.

The purpose of this paper is to provide preliminary results of charcoal radiocarbon dates obtained from a fan in the Peace River area of northeastern $\mathrm{BC}$ and to begin establishing a prehistoric fire history for the area. Refinement of these results is forthcoming as charcoal dates from other fans in the area will be added to the database. Results of this study also have implications for local glacial refugia, but this topic is beyond the scope of this paper and will be dealt with in a subsequent publication.

\section{SETTING}

Our study site is located on a fan on a fluvial terrace of the Peace River (see Figure 1), at a location (Figure 2) known as Bear Flat $\left(56^{\circ} 16^{\prime} 51^{\prime \prime} \mathrm{N}, 121^{\circ} 13^{\prime} 39^{\prime \prime} \mathrm{W}\right)$. The site is located in a drier portion of the Peace variant of the Black and White Boreal Spruce biogeoclimatic zone (DeLong 1998; Meidinger and Pojar 1991) and is influenced by southern exposure in the Peace River valley. The slopes are often covered with aspen (Populus tremuloides) forest or grassland steppe. The Bear Flat 
site has been farmed since at least 1949-the time of the earliest aerial photographs. An aerial photograph of the area is given in Figure 1. The site was selected because it exposed an excellent record of paleosols and because there are no published results on long-term forest-fire history this far north in $\mathrm{BC}$.

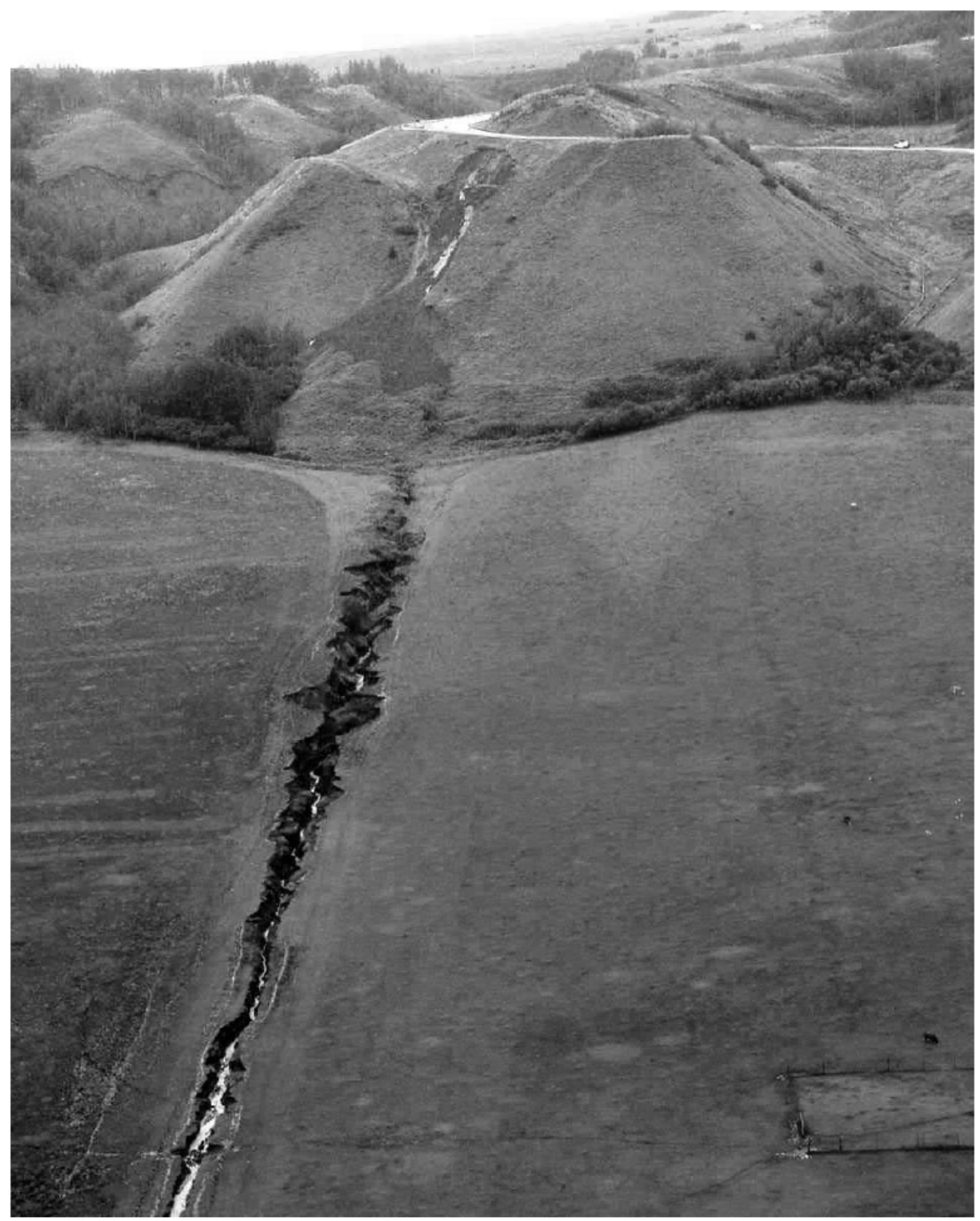

Figure 1 Oblique aerial photograph of the alluvial fan at Bear Flat, BC

In addition, the region is close to the area of coalescence of the Cordilleran and Laurentide ice sheets (Catto et al. 1996) and was covered by Glacial Lake Peace at the end of the Pleistocene. A date on wood charcoal on Lake Peace sediments overlying the Laurentide ice sheet till in the Fort St. John region gave an age of $13,970 \pm 170{ }^{14} \mathrm{C}$ yr BP (Catto et al. 1996), equivalent to a calibrated age 


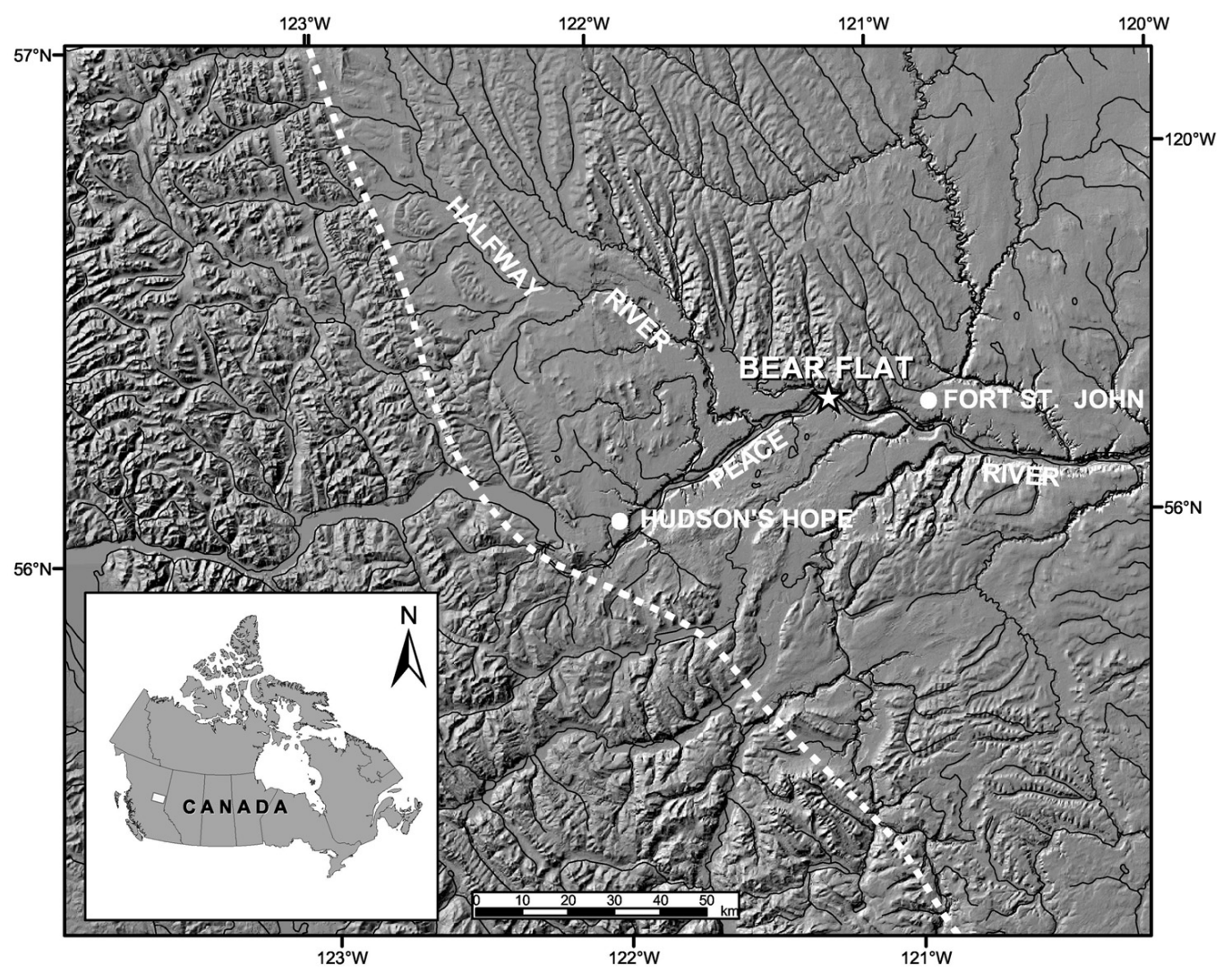

Figure 2 Location of Bear Flat adjacent to the Peace River, northern BC. Note the location of the maximum western extent of the Laurentide ice sheet (dotted line), estimated by Catto et al. (1996) from the distribution of Laurentide erratics. These authors also reported a ${ }^{14} \mathrm{C}$ date on wood charcoal, from the contact of Laurentide till and overlying Glacial Lake Peace sediments in the Fort St. John region, of $13,970 \pm 170{ }^{14} \mathrm{C}$ yr BP $(15,500-14,200$ cal BP).

range of 17,450-16,150 cal BP. Also, dates on terrestrial plants confirm that this area was ice-free by $\sim 12,500{ }^{14} \mathrm{C}$ yr BP; in calibrated years, this corresponds to an age range of $15,600-14,200 \mathrm{cal} \mathrm{BP}$, as reported by Dyke et al. (2001).

\section{Contributing Catchment Area}

The fan at Bear Flat (Figure 3) has been mapped as a colluvial clay fan of the Taylor soil association (Lord and Green 1986). The fan has a gentle gradient with a mid to distal slope of 6\%, indicating gentle low-energy deposition, ideal for the preservation of buried horizons. The fan is similar to the arid fans described by Bull (1964) and is responsive to flash flood deposition. The fan contains numerous charcoal-rich horizons (see Figure 4). In our model, charcoal accumulated in 2 ways: 1) as detritus entrained in alluvial and colluvial sediment flows from the adjacent hillslopes subsequent to fire (and during other erosion events); and 2) from material burned in situ. While wind deposition of charcoal is also possible, the fan sediments were not as such identified as eolian materials. The size of the charcoal delivering catchment varied with time. During the Wisconsin glaciation, prior to the development of Glacial Lake Peace (Matthews 1980), isolated refugia may have existed perhaps with rare fires or with preserved wood burning at much later dates. The locations of these refugia are unknown 

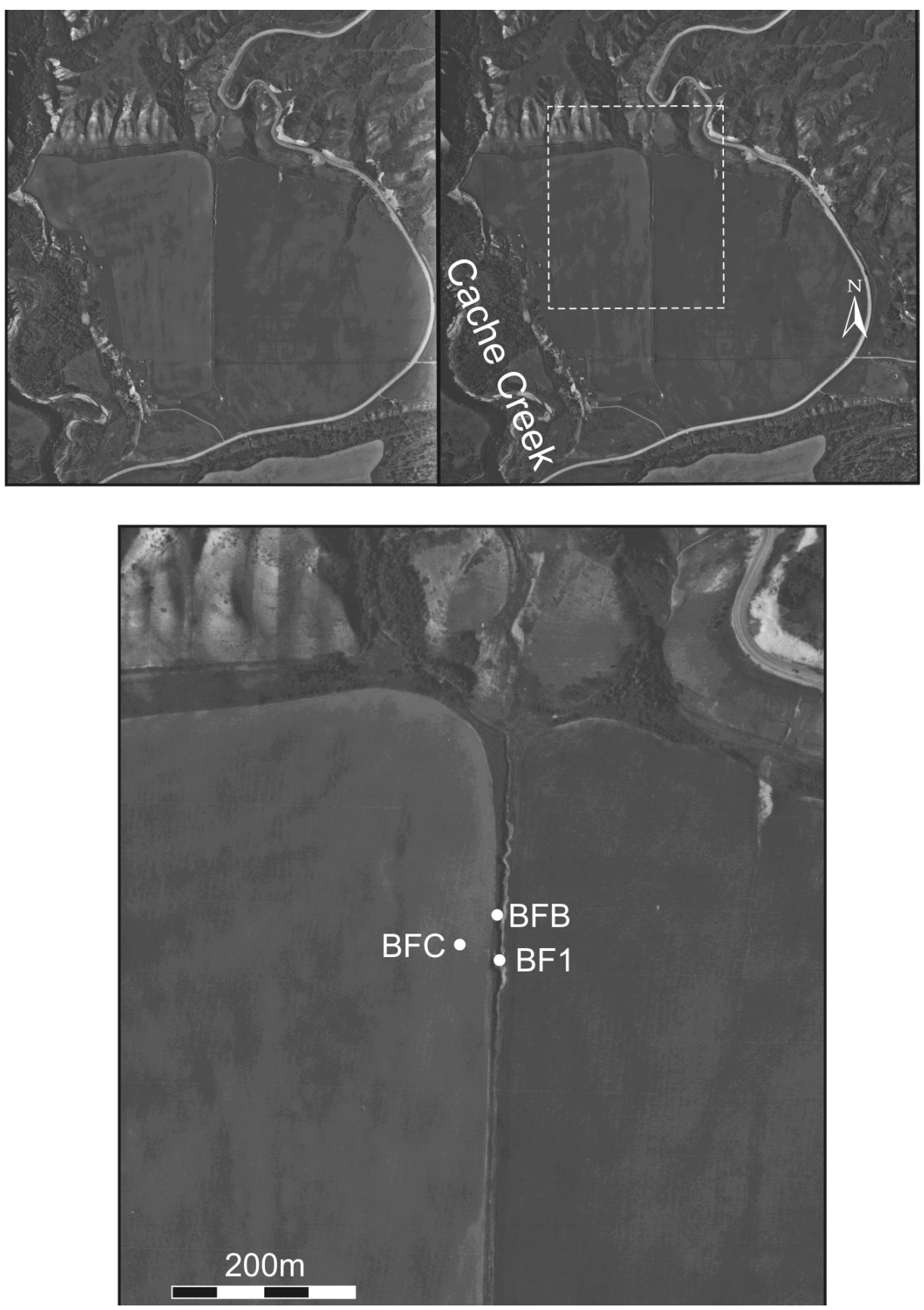

Figure 3 a) Stereo image of the Bear Flat site. b) Detailed view of the Bear Flat fan showing the specific locations of the 3 cores: $\mathrm{BF} 1, \mathrm{BFB}$, and $\mathrm{BFC}$.

to us, but presumably occurred near the zone of coalescence of the Laurentide and Cordilleran ice sheets. Indeed, these may have been shifting refugia. Later, as Glacial Lake Peace emerged and went through various stages of growth, charcoal from refugia and from contemporaneous fires in the local 
contributing watershed may have been collected in and redistributed through the ice-dammed lake. This charcoal is stored in the sediments of Glacial Lake Peace and redistributed by landslides and erosive transport. After the ice dam broke and Glacial Lake Peace drained, the Peace River incised itself through the lake sediments, constructing several tiers of terraces. The fan at Bear Flat is constructed on one of these terraces. Transport of charcoal from fires postdating the construction of the fan comes from a much smaller local catchment area. Charcoal predating the fan could have arrived from a much larger area and thus has an uncertain provenance. We recognize that it may not be possible to rule out eolian transport of some fine-grained material, as Valentine et al. (1980) described a section further to the east along the Peace River with eolian deposits in a clifftop dune. Nonetheless, the ages are important as they represent times of at least isolated unglaciated conditions.

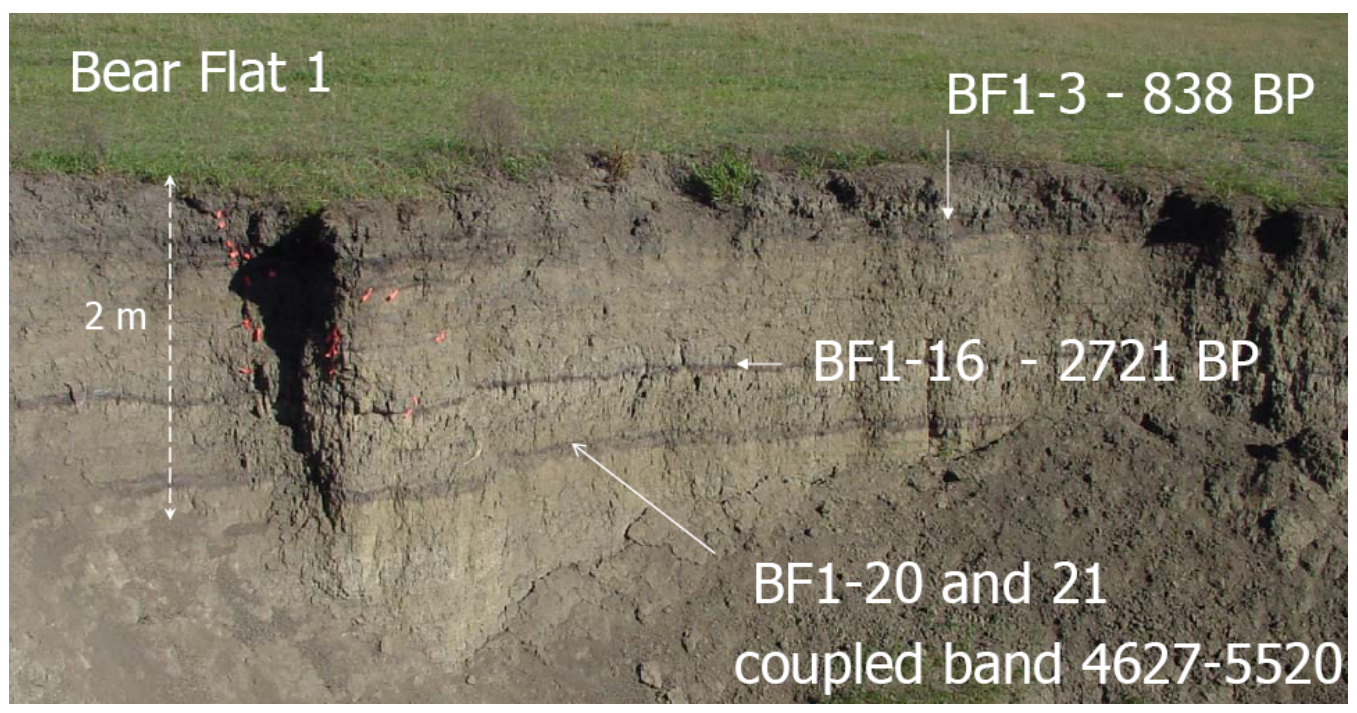

Figure 4 View of the exposure of the buried fire horizons at the Bear Flat 1 location. Discrete charcoal horizons are marked with the red tags, and major fire events are clearly visible in this photograph.

\section{METHODS}

We sampled charcoal and charcoal-rich sediments from paleosols, some of which are fire-reddened at a gully incised into the fan (Figure 4). The sampling locations (see Figure 2b) occurred in the mid to distal portion of the fan at 2 exposures and from 1 drilled core. The core was extracted using Shelby tubes and the split spoon method. As noted in Table 1, many samples contained macroscopic charcoal, and other horizons were found to contain apparently macroscopic charcoal, which fell apart during pretreatment to give a mixture of sediment and finely divided material. Where possible, we treated charcoal fragments samples using the conventional acid-alkali-acid cleaning procedure (Bird, forthcoming). Charcoal fragments were picked from the cleaned material and combusted in the presence of $\mathrm{CuO}$ to $\mathrm{CO}_{2}$. The gas was then reduced to graphite for accelerator mass spectrometry (AMS) dating. In some cases, macroscopic charcoal was not present after pretreatment, as some samples were mostly fine clay-rich mineral sediment, or the charcoal fragments disintegrated after pretreatment. In these cases, it was not possible to separate finely dispersed charcoal $(<0.1 \mathrm{~mm})$ from these materials. These samples were pretreated with the acid-base-acid treatment, washed, dried, and then combusted at $400{ }^{\circ} \mathrm{C}$ in oxygen (McGeehin et al. 2001), which should only sample the organic carbon. 


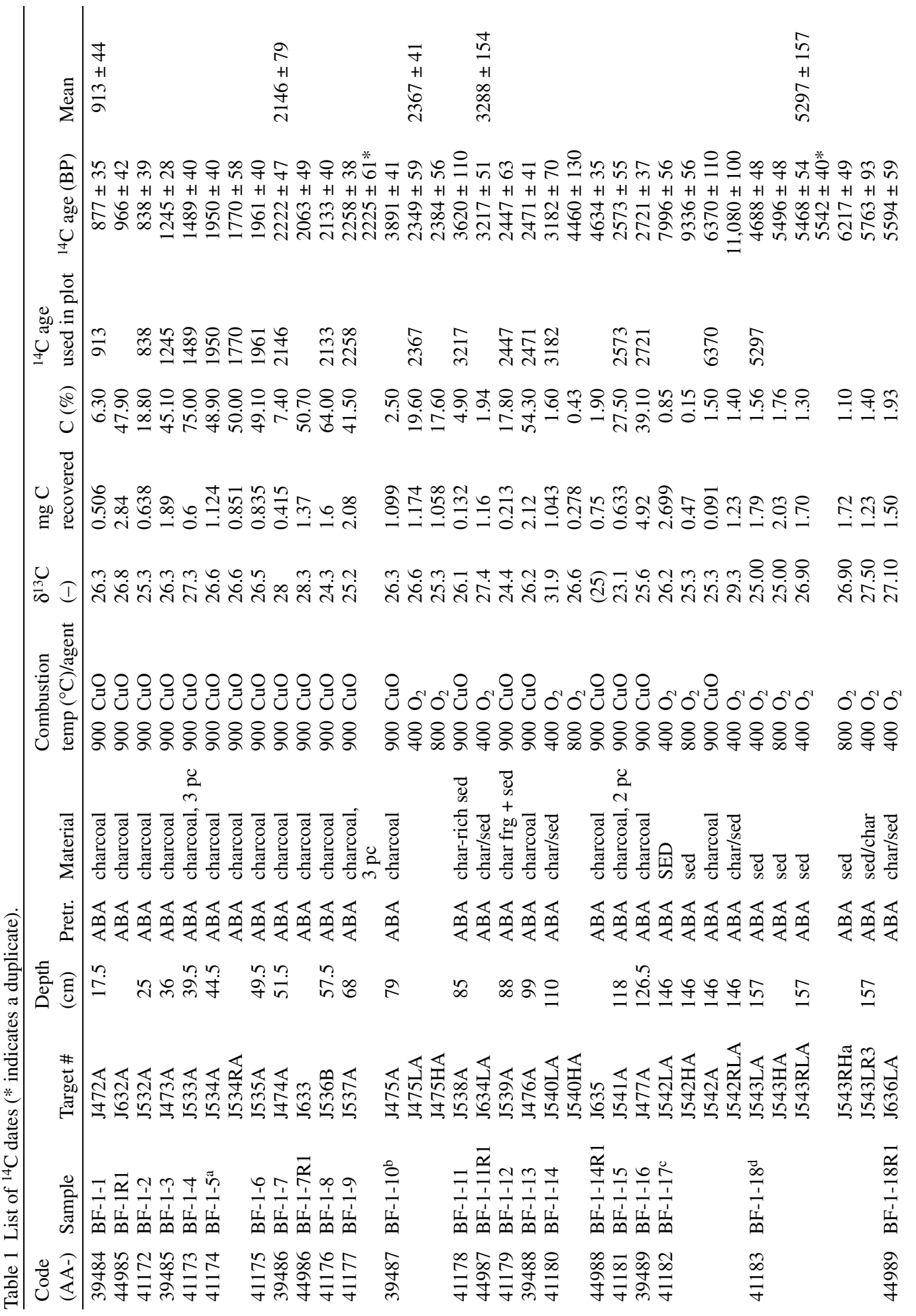




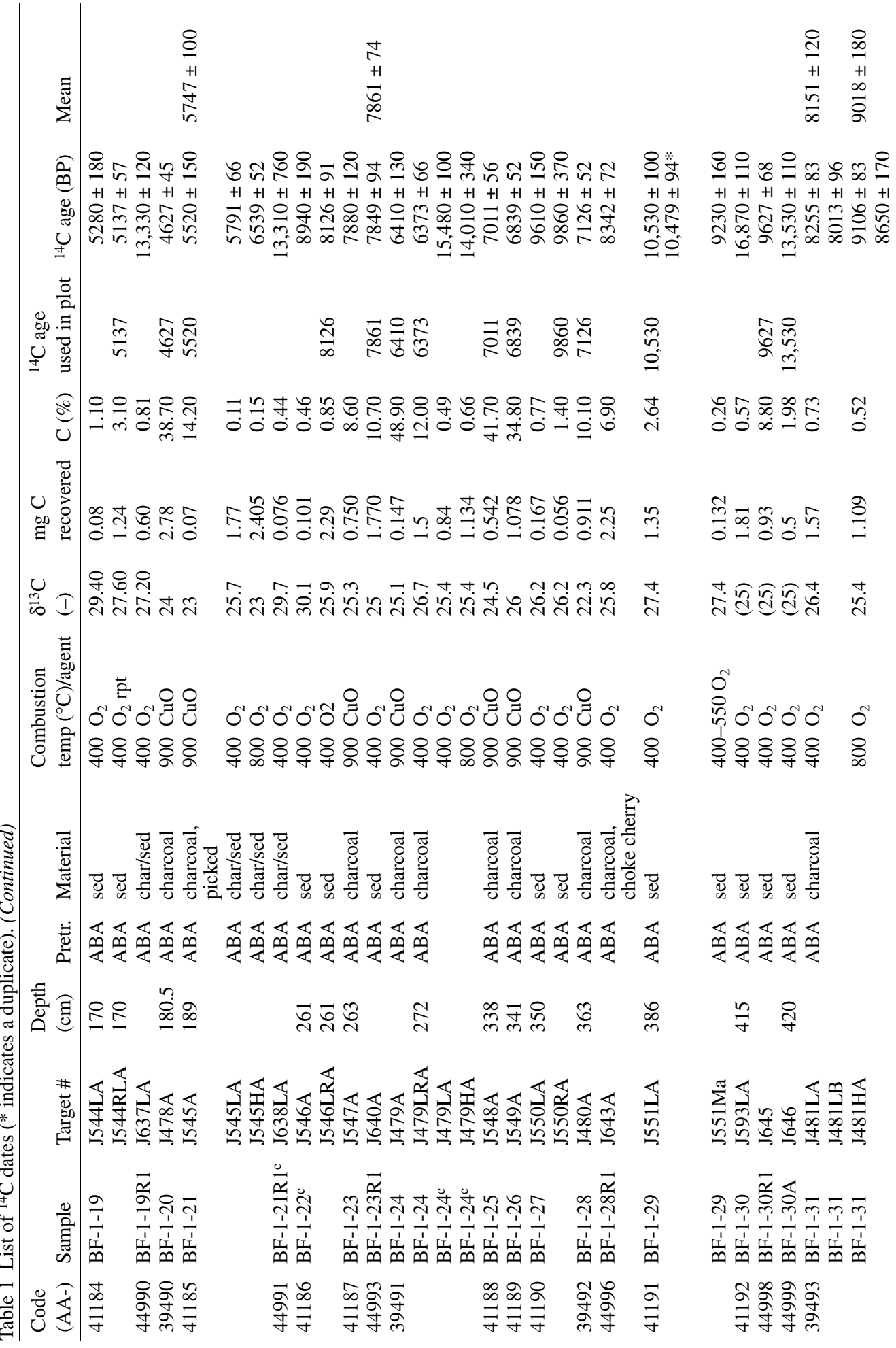




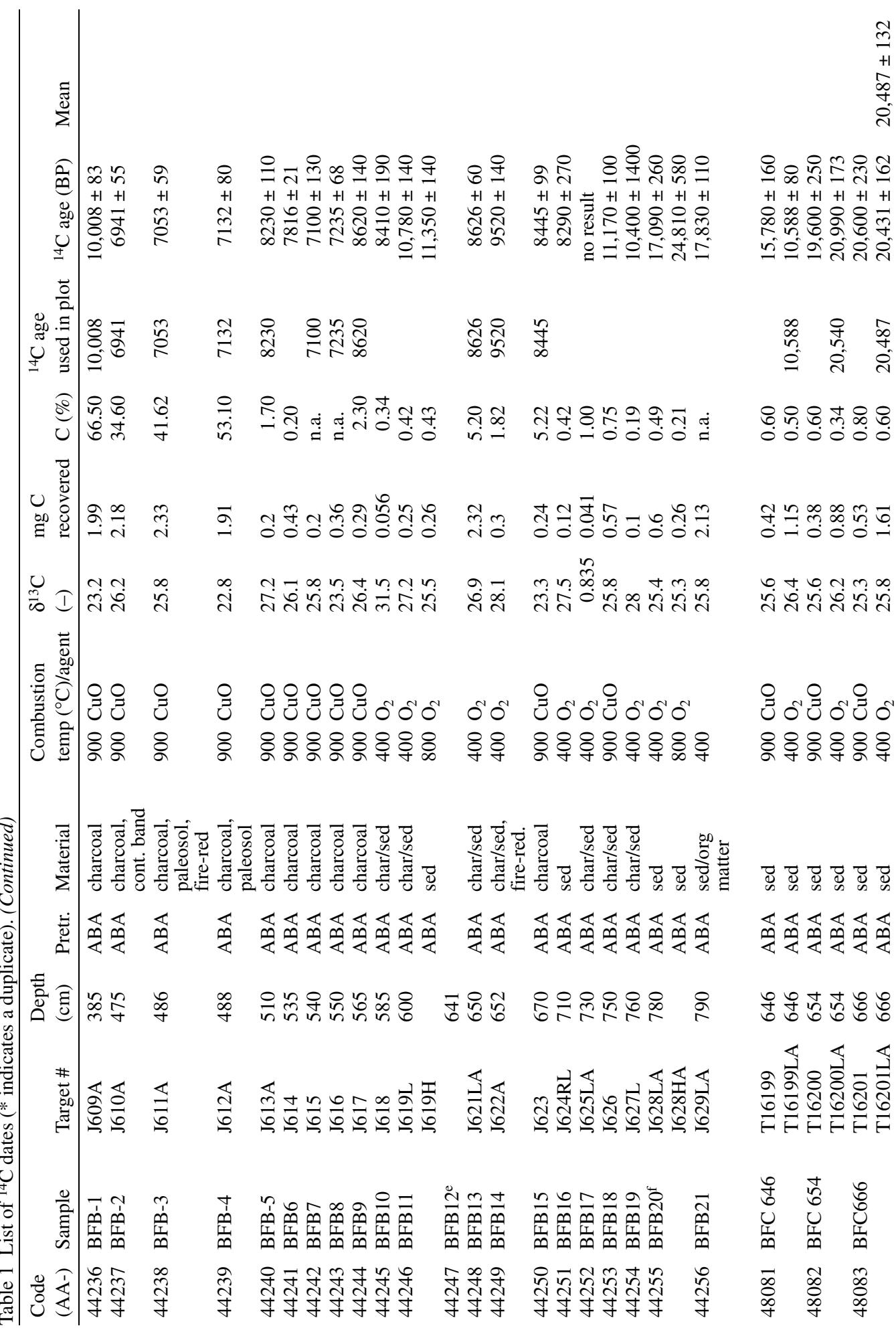




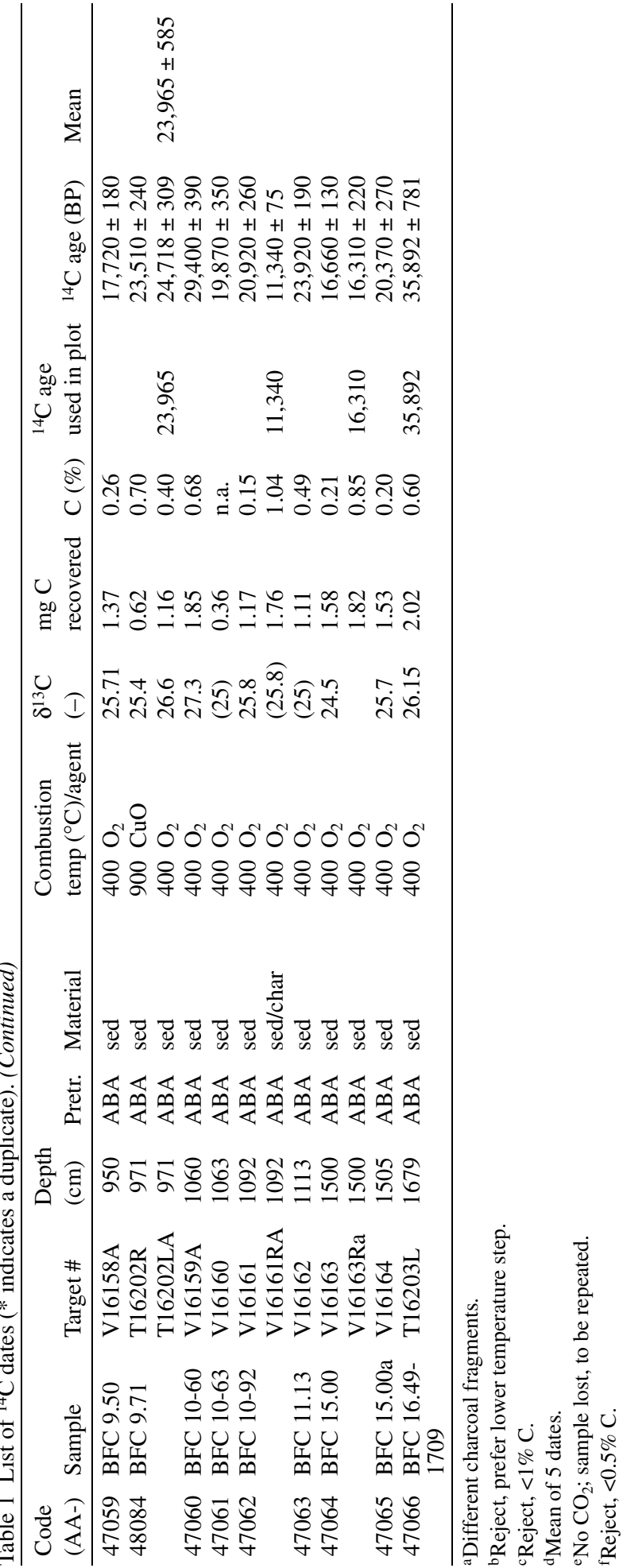




\section{RESULTS AND DISCUSSION}

It is important to establish the age of the fan to separate the older and larger contributing catchment from the younger and smaller Holocene catchment. To do this, we attempt to distinguish between in situ and detrital charcoal. We distinguish horizons with occasional charcoal fragments from horizons with continuous bands of charcoal, and attribute the former to detrital charcoal (transported either a long or a short distance) and the latter to possible in situ charcoal. Strong evidence for in situ charcoal is an intact subjacent fire-reddened horizon (Dormaar and Lutwick 1975). Ketterings and Bigham (2000) note that soil reddening occurs when the soil has been heated to $>600{ }^{\circ} \mathrm{C}$ for over 45 min. It is difficult to envision large-scale mass transport of such a horizon without brecciating. In addition, we feel that dating larger macroscopic charcoal is more reliable than smaller fragments, as they can be transported relatively long distances by wind.

The lowest fire-reddened material is encountered at $420 \mathrm{~cm}$ depth and yields an age of 16,250 \pm 700 cal BP. As the long-distance transport of charcoal with fire-reddened sediment is unlikely, this may represent a minimum age of the fan and thus a minimum age for the drainage of Glacial Lake Peace. The oldest continuous charcoal layer at $386-\mathrm{cm}$ depth yields an age of $10,530 \pm 100{ }^{14} \mathrm{C} \mathrm{yr} \mathrm{BP}$, which gives a calibrated range of 10,780-10,306 $\mathrm{BC}(1 \sigma)$ and 10,845-10,198 $\mathrm{BC}(2 \sigma)$. This age postdates the age range of 15,600-14,200 BP of Dyke et al. (2001) of a minimum age of Glacial Lake Peace. Our study does not solve this deglacial landscape issue, but provides additional data for consideration.

\section{Difference in Ages of Charcoal}

We assessed the problem of sampling different-aged charcoals by dating more than 1 sample from the same horizon. Reasonable agreement was obtained, but with differences ranging from 31 to $1280{ }^{14} \mathrm{C}$ yr BP. This study of 7 duplicates gave a mean difference of $360{ }^{14} \mathrm{C} \mathrm{yr}$ and a standard error $(1 \sigma)$ of $380 \mathrm{yr}$. One horizon (BF1-17; $146 \mathrm{~cm})$ gave a wide range of ${ }^{14} \mathrm{C}$ ages. In such cases where different results were obtained, it is not clear if material from the same tree was dated, or the charcoal was derived from several fires of different ages, older charcoal was incorporated, or if fine older charcoal was present in the dated sample for some other reason, as discussed by Lertzman et al. (2002). Clearly, such effects limit the accuracy of dating fire recurrence in soils at the century scale.

\section{Dating of Fire and Fire-related Horizons}

A complete list of our results for Bear Flat is given in Table 1. In Figure 5, we show results for samples from 50 charcoal horizons that yielded $>1 \% \mathrm{C}$. We also include results of 6 samples below $\sim 6.5-\mathrm{m}$ depth that yielded $0.3-1.0 \% \mathrm{C}$ during combustion. These samples contained scattered small pieces of charcoal, and we used the $\mathrm{C}$ content as an estimate of the significance of these samples. Some other samples with as little as $0.2 \% \mathrm{C}$ were measured, but these showed a wide scatter in age and were excluded from Figure 5 on the basis of their very low $\mathrm{C}$ yield, since these dates could easily be affected by detrital carbon or eolian transport of older carbon. Amounts of carbon dated range from 0.04 to $2.8 \mathrm{mg}$. In order to avoid confusion, we will refer to all ages in calibrated years before present (cal BP), although we include ${ }^{14} \mathrm{C}$ ages in Table 1 . Calibrated ${ }^{14} \mathrm{C}$ ages were obtained using the IntCal04 calibration (Reimer et al. 2004).

The sediment sequence in the Bear Flat fan contains several large, thick charcoal-rich horizons, some of which are fire-reddened (see Figure 4), as well as less distinct layers without fire-reddening that also contain charcoal. The most recent fires, observed in this record, occurred during the Medieval Warm Period (MWP), with 2 charcoal-rich horizons dated at $913 \pm 44$ and $838 \pm 39{ }^{14} \mathrm{C} \mathrm{yr} \mathrm{BP}$, corresponding to 2- $\sigma$ confidence limits of 930-730 cal BP and 910-670 cal BP, respectively; how- 


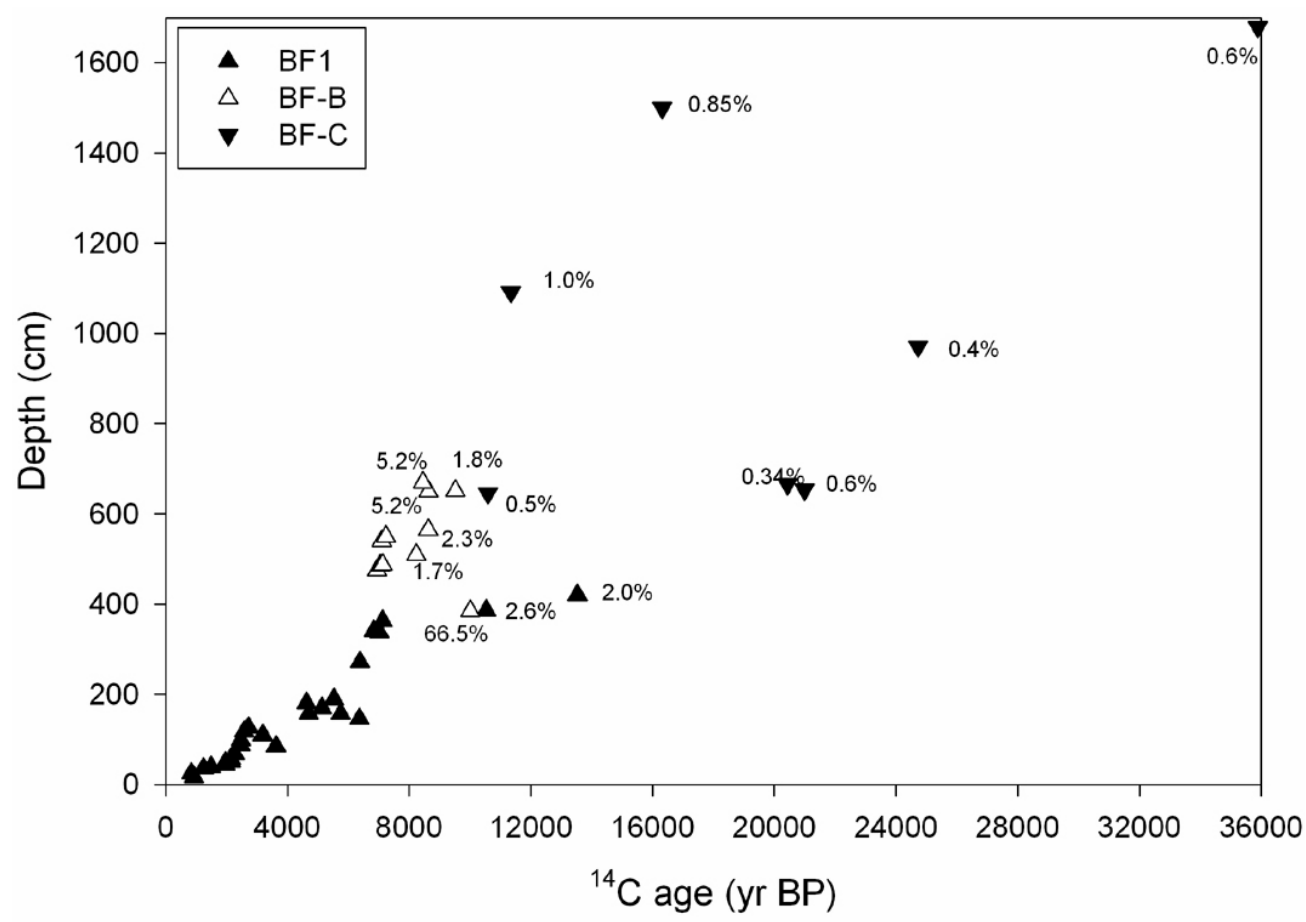

Figure 5 Plot of ${ }^{14} \mathrm{C}$ ages of the charcoal-rich soil horizons versus depth. Note the divergence of the plot beyond $8000{ }^{14} \mathrm{C}$ yr BP. The carbon yields on combustion of some of the older samples are shown, including the 6 samples yielding $<1 \%$ C. Samples where no yield is indicated all gave much larger yields of carbon on combustion.

ever, in the second case, $85 \%$ of the probability is between $800-670$ cal BP. Obviously, there may have been very localized fires that are not seen in our record. We can also compare these results to evidence for MWP fires from other locations in BC (Gavin et al. 2003a,b; Hallett et al. 2003a,b). The presence of the MWP even in very different biogeoclimatic zones indicates its global effects.

As can be seen in Table 1, charcoal ages generally increase with depth, although there is an inversion at about $475 \mathrm{~cm}$. We attribute the inversion to a debris flow off the adjacent slopes at about 13,500 \pm $110{ }^{14} \mathrm{C}$ yr BP (i.e. $16,950-15,550 \mathrm{cal} \mathrm{BP}$ ), subsequent to a fire recorded in the sediment at about that time. Horizons below this depth or $\sim 11,000 \mathrm{cal} \mathrm{BP}$ yielded ${ }^{14} \mathrm{C}$ ages ranging from 7600 to over $12,000 \mathrm{cal}$ BP. Considering all the dates, the oldest definite fire-reddened, but non-continuous, horizon is about $16,250 \pm 700 \mathrm{cal} \mathrm{BP}$. We interpret this lower charcoal to be redeposited and mixed by debris flow or fluvial transport. Detrital charcoal fragments below this horizon yielded ages ranging from 19,500 to $36,000 \mathrm{cal}$ BP. These ages should be treated with considerable caution as they are based on sediments that had low yields of carbon $(0.34-0.6 \% \mathrm{C})$. Nevertheless, they plot on the same age-depth curve as the other samples. This trend suggests that these old dates likely represent the true ages of the charcoal, and they are not mixtures of material of different ages, though the latter possibility cannot be ruled out. In the latter case, the low-carbon sediment ages are likely overestimates of the true age of the deposit, due to admixture of older material. The presence of charcoal of these ages suggests that this area may have been ice-free during much of the last 36,000 yr. 


\section{DISCUSSION}

We have summarized our results as a cumulative plot of age probability distributions in Figure 6. This distribution was obtained by summing the probability ranges of all the calibrated ${ }^{14} \mathrm{C}$ ages. We summed the probability distributions derived from Calib 5.0 (Reimer et al. 2004), which is the same method employed by Meyer et al. (1995) and Pierce et al. (2004), except they used an older version of the calibration. This plot shows striking increases in fire at several periods (e.g. 2000-3000 cal $\mathrm{BP}, \sim 6000 \mathrm{cal} \mathrm{BP}, 7500-8000 \mathrm{cal} \mathrm{BP}$, and $9500-10,000 \mathrm{cal} \mathrm{BP}$ ). The probability shown on the vertical axis is an estimate of the instantaneous probability of fire, assuming all fires are sampled. This assumption may not be entirely accurate, since we need a large enough fire to trigger erosion of adjacent hillslopes to aggrade the fan deposits.

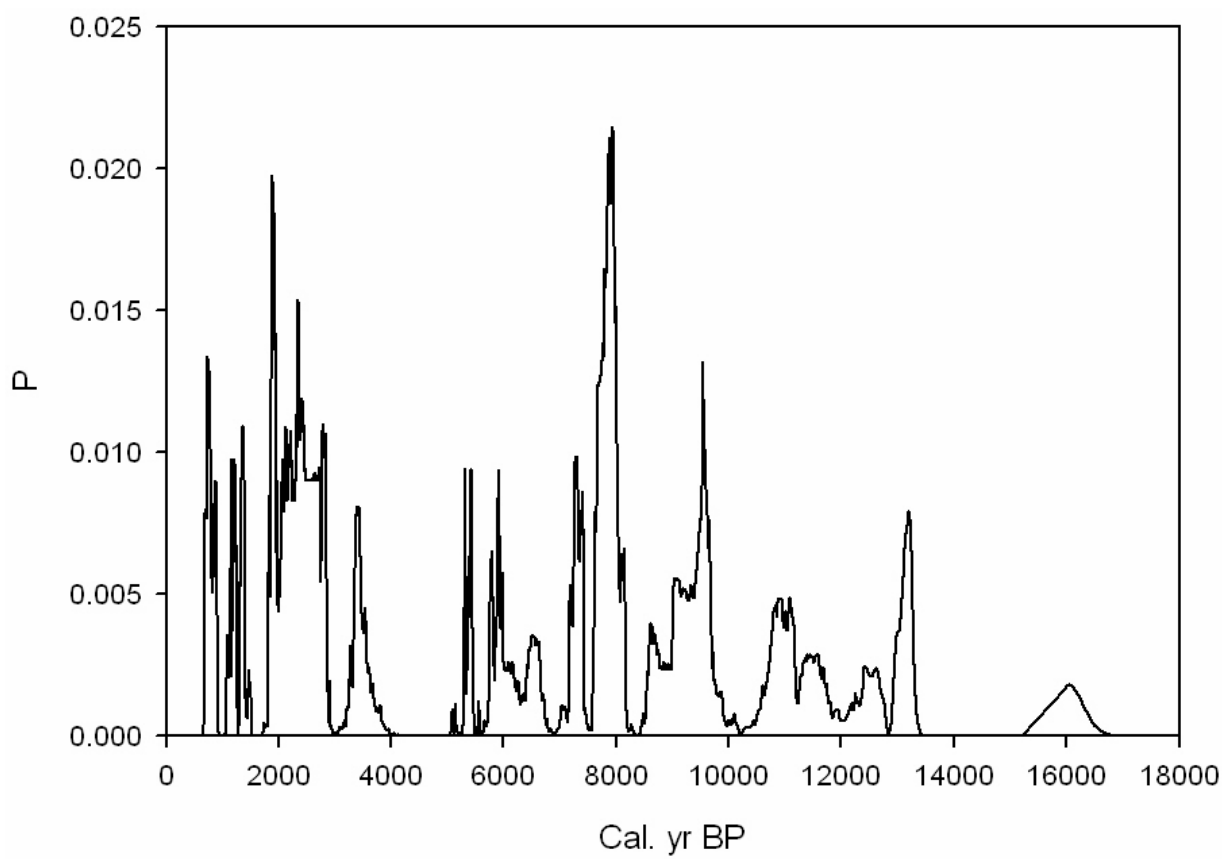

Figure 6 Plot of combined probability distributions (calculated from IntCal 98, Stuiver et al. 1998) for the last 16,000 $\mathrm{yr}$ of forest fires at Bear Flat, BC. The probability shown on the vertical axis is from the sum of the ${ }^{14} \mathrm{C}$ probability curves (Reimer et al. 2004).

The uppermost buried fire horizon (17-18 cm depth) gave an age of $913 \pm 44{ }^{14} \mathrm{C}$ yr BP $(920-760$ $\mathrm{BP}[1 \sigma] ; 930-730 \mathrm{cal} \mathrm{BP}[2 \sigma])$ based on 2 independent determinations of $877 \pm 35$ and $966 \pm 42$ ${ }^{14} \mathrm{C}$ yr BP, where these dates were on separate discrete fractions of charcoal. Although the youngest age appears older than other records (e.g. Pierce et al. 2004; Sanborn et al. 2006), late-Holocene fire frequencies at Bear Flat are similar or lower than those inferred at other locations (Long et al. 1998; Hallett et al. 2003a; Millspaugh et al. 2000; Lertzman et al. 2002; Hallett and Walker 2000). It is possible that the youngest records have been removed by 20th century agricultural ploughing.

A lower rate of fires characterizes both the Younger Dryas period (11,000-12,900 cal yr, see Alley et al. 1993) and the preceding period. There is a marked increase in fire frequency to $\sim 6$ fires $/ \mathrm{kyr}$ during the period 10,000 to $9000 \mathrm{cal} \mathrm{BP}$, with a peak at $\sim 9500 \mathrm{cal} \mathrm{BP}$. No fire events are recorded for a short interval after $8500 \mathrm{cal} \mathrm{BP}$. After $8300 \mathrm{cal} \mathrm{BP}$, there is a considerable increase to $\sim 10$ fires/ 
$10^{3} \mathrm{yr}$, with a peak of $\sim 13$ fires $/ 10^{3} \mathrm{yr}$ at $8000 \mathrm{cal}$ BP. This is followed by a period of no fires and then fires at a rate of $4-6$ fires $/ 10^{3} \mathrm{yr}$ continues until $~ 5500 \mathrm{cal}$ BP. The period of $4000-5000 \mathrm{cal} \mathrm{BP}$ records no fires in our record. Fires increase to an average of 8 fires $/ 10^{3} \mathrm{yr}$ over the entire period of 2000 to $3000 \mathrm{cal} \mathrm{BP}$, with a peak value of 12 fires $/ 10^{3} \mathrm{yr}$. The record from $800-2000 \mathrm{cal} \mathrm{BP}$ indicates a lower frequency of $<4$ fires $/ 10^{3} \mathrm{yr}$.

The early Holocene in western North America is a time of warm, dry conditions, which may explain the high fire frequency from 9000 to $8000 \mathrm{cal} \mathrm{BP}$. A global cold event is known around $8200 \mathrm{cal} \mathrm{BP}$, probably caused by the draining of Glacial Lake Agassiz and other large lakes at the time (Barber et al. 1999), which may have disrupted the North Atlantic thermohaline circulation. It is interesting to note a rapid increase in fire frequency just after that time. Climatic periodicity on a millennial scale has been observed in the North Atlantic record of ice-rafted debris (Bond et al. 1997), attributed to solar forcing (Bond et al. 2001; Braun et al. 2005) or oceanic circulation changes (Alley et al. 1999). We observed that only some ice-rafting events in the North Atlantic appear to coincide with or precede periods of increased fires in our record by $\sim 200 \mathrm{cal}$ yr.

Although several authors have asserted that decadal- and century-scale climate phenomena control fire recurrence (Masters 1990; Johnson 1992; Johnson et al. 1990; Johnson and Larsen 1991; Johnson and Wowchuk 1993), the charcoal record itself limits such interpretations. It is not possible to infer fire frequency at time scales of less than a century using ${ }^{14} \mathrm{C}$ dating of fossil charcoal. Most forest fires are generally considered to be "stand-replacing" fires occurring at intervals of $\sim 200 \mathrm{yr}$, and this can be understood as the reason for the underlying rate of fires of about $4-5 / 10^{3} \mathrm{yr}$ during the Holocene.

It has also been noted by many authors that forest-fire frequency in some regions is climatically controlled, e.g. in Yellowstone (Meyer et al. 1995; Millspaugh et al. 2000), Idaho (Meyer et al. 2001), Oregon (Long et al. 1998), southwestern BC (Gavin et al. 2003b; Hallett et al. 2003a; Lertzman et al. 2002), and southeastern BC (Hallett and Walker 2000; Hallett et al. 2003b). This signal appears less marked in the tropics (Horn and Sanford 1992; Turcq et al. 1998) and in other mid-latitude regimes, such as in eastern Canada (Carcaillet et al. 2001) and New Zealand (Molloy et al. 1963).

Cumming et al. (2002) reported on persistent millennial-scale effects on moisture availability recorded at Big Lake, BC, in the semi-arid Cariboo region, some $500 \mathrm{~km}$ south of the Bear Lake site. It is also important to note recent studies, such as those of cyclic variations in an Alaskan lake, reported by Hu et al. (2003), which suggest millennial-scale periodicity. In other records from the northwestern USA, Whitlock et al. (2003) summarized the fire records observed in lake sediments from a number of lakes at $40-45^{\circ} \mathrm{N}$. Several of these records showed millennial-scale periodicity, but they were not all in phase with the other records.

Records of forest fires at Yellowstone National Park indicated an increase in fire frequency at 9000 to 8200 BP (Millspaugh et al. 1998), followed by an abrupt reduction during the global cold event around $8200 \mathrm{cal} \mathrm{BP}$ (Barber et al. 1999). Millspaugh et al. (1998) suggested a trend related primarily to solar insolation, though more detailed dating suggests a link to millennial-scale phenomena (see also Meyer et al. 1995). The results of Meyer et al. (1995), discussed by Meyer and Pierce (2003), suggest an anti-correlation with Bond cycles and also a response to century-scale events such as the MWP and the Little Ice Age. Meyer and Pierce (2003) also compared the Yellowstone results to those from Idaho (Meyer et al. 2001). In this study, we note that the Bear Flat record shows evidence for fires during the MWP, but earlier fires appear to show a comparable millennial-scale trend to the Yellowstone results. However, when looking at the 2 records in detail, there is only a weak correspondence to some Yellowstone events such as about 2500, 6300, and $8200 \mathrm{cal} \mathrm{yr}$, whereas other 
features are not correlated. This suggests that each region has its own response to long-term climatic forcing.

It is also interesting to consider the implications of this fire record for deglaciation in this region. The lowest fire-reddened soil horizon containing observable charcoal is dated to $15,644-16,659 \mathrm{cal}$ BP, shown as a broad peak in Figure 4, which implies that this area was already deglaciated and at least partly forested at that time. This early deglaciation is consistent with other early dates on wood charcoal and terrestrial plant fragments from this region (Catto et al. 1996; Dyke et al. 2001). Catto et al. (1996) also estimated the area might have been ice-free by as early as 18,750-17,550 cal BP.

It is also important to consider the impact of aboriginal peoples, who cleared land with fire and have been in this area since about 13,000 cal BP (White and Mathewes 1986; Fladmark et al. 1988). Although studies in Europe have suggested that such fires would then not be linked to climate, other workers have suggested that fires started by humans can also be climate-linked, as periods of drought would tend to allow fires to spread.

\section{CONCLUSIONS}

We believe our record of forest fires from a continuous record from 1 site is important, since we study dates of fire-related debris from 1 small catchment, as opposed to the integration of several locations (e.g. Pierce et al. 2004). The record also shows a record of forest fires beginning in Late Glacial times, consistent with the deglaciation history of the region (Catto et al. 1996). We consider this forest-fire record to represent an important record of past climatic changes, and the record from Bear Flat shows a response to the Medieval Warm events; earlier, fires appear to have a millennialscale variability. The record shows the effects of long-term periodicity in fire response, which must be linked to regional and global climatic conditions over the late Glacial and early Holocene. As more such records become available, it will be important to try to link these diverse expressions of climatic change with global models of climate and fire regimes over time.

\section{ACKNOWLEDGMENTS}

This work was supported in part by Forest Renewal British Columbia, Canadian Forest Products Ltd., and the US National Science Foundation, grant EAR 01-15488 and EAR04-48461. We are grateful to J J Clague and G S Burr for useful discussions and to P Sanborn and B Hawkes for their thorough reviews of this manuscript. Richard Hebda helped with some sampling and provided useful discussions in the field. We gratefully acknowledge the technical assistance of staff members of the NSF Arizona AMS Laboratory.

\section{REFERENCES}

Alley RA, Meese DA, Shuman CA, Gow AJ, Taylor KC, Grootes PM, White JWC, Ram M, Waddington ED, Mayewski PA, Zielinski GA. 1993. Abrupt increase in Greenland snow accumulation at the end of the Younger Dryas. Nature 362:527-9.

Alley RA, Clark PU, Keigwin LD, Webb RS. 1999. Making sense of millennial-scale climate change. In: Clark PU, Webb RS, Keigwin LD, editors. Mechanisms of Global Climate Change at Millennial Time Scales. Washington, D.C.: Geophysics Monograph, American Geophysical Union. Volume 112. p 385-94.

Barber DC, Dyke A, Hillaire-Marcel C, Jennings AE, Andrews JT, Kerwin MW, Bilodeau G, McNeely R,
Southon J, Morehead MD, Gagnon JM. 1999. Forcing of the cold event of 8,200 years ago by catastrophic drainage of Laurentide lakes. Nature 400:344-8.

Bird MI. Forthcoming. Radiocarbon dating of charcoal. In: Elias SA, editor. Encyclopedia of Quaternary Sciences. Oxford: Elsevier.

Bond G, Showers W, Cheseby M, Lotti R, Almasi P, deMenocal P, Priore P, Cullen H, Hajdas I, Bonani G. 1997. A pervasive millennial-scale cycle in North Atlantic Holocene and glacial climates. Science 278: 1257-66.

Bond G, Kromer B, Beer J, Muscheler R, Evans MN, Showers W, Hoffmann S, Lotti-Bond R, Hajdas I, Bo- 
nani G. 2001. Persistent solar influence on North Atlantic climate during the Holocene. Science 291: 2130-5.

Braun H, Christl M, Rahmsdorf S, Ganopolski A, Mangini A, Kubatski C, Roth K, Kromer B. 2005. Possible solar origin of the 1,470-year glacial climate cycle demonstrated in a coupled model. Nature 438 : 208-11.

Bull WB. 1964. Alluvial fans - near-surface subsidence in western Fresno County, California. United States Geological Survey Professional Paper 437-A.

Carcaillet C. 1998. A spatially precise study of Holocene fire history, climate and human impact within the Maurienne Valley, north French Alps. Journal of Ecology 86:384-96.

Carcaillet C, Bergeron Y, Richard PJH, Frechette B, Gauthier S, Prairie YT. 2001. Change of fire frequency in the eastern Canadian boreal forests during the Holocene: Does vegetation composition or climate trigger the fire regime? Journal of Ecology 89:93046.

Catto N, Liverman DGE, Bobrowksy PT, Rutter N. 1996. Laurentide, Cordilleran and Montane glaciation in the western Peace River Grande Prairie region, Alberta and British Columbia, Canada. Quaternary International 32:21-32.

Cumming BF, Laird KR, Bennett JR, Smol JP, Salomon AK. 2002. Persistent millennial-scale shifts in moisture regimes in western Canada during the last six millennia. Proceedings of the National Academy of Sciences, USA 99:16,117-21.

Cwynar LC. 1987. Fire and the forest history of the North Cascade Range. Ecology 68:791-802.

DeLong C. 1998. Natural disturbance rate and patch size distribution in forests in northern British Columbia: implications for forest management. Northwest Science 72:35-48.

Dormaar JF, Lutwick LE. 1975. Pyrogenic evidence in paleosols along the North Saskatchewan River in the Rocky Mountains of Alberta. Canadian Journal of Earth Science 12:1238-44.

Dyke AS, Andrews JT, Clark PU, England JH, Miller GH, Shaw J, Veillette JJ. 2001. Radiocarbon dates pertinent to defining the last glacial maximum for the Laurentide and Innuitian ice sheets. Open File report 4120, Geological Survey of Canada.

Fladmark KR, Driver JC, Alexander D. 1988. The Palaeoindian component at Charlie Lake Cave (HbRf 39), British Columbia. American Antiquity 53(2):371-84.

Gavin DG, Brubaker LB, Lertzman KP. 2003a. Holocene fire history of a coastal temperate rain forest based on soil charcoal radiocarbon dates. Ecology 84:186-201.

Gavin DG, Brubaker LB, Lertzman KP. 2003b. An 1800year record of the spatial and temporal distribution of fire from the west coast of Vancouver Island, Canada. Canadian Journal of Forest Research 33:573-86.

Hallett DJ, Walker RC. 2000. Paleoecology and its appli- cation to fire and vegetation management in Kootenay National Park, British Columbia. Journal of Paleolimnology 24:401-14.

Hallett DJ, Lepofksy DS, Mathewes RW, Lertzman KP. 2003a. 11,000 years of fire history and climate in the mountain hemlock rain forests of southwestern British Columbia based on sedimentary charcoal. Canadian Journal of Forest Research 33:292-312.

Hallett DJ, Mathewes RW, Walker RC. 2003b. A 1000year record of forest fire, drought and lake-level change in southeastern British Columbia. The Holocene 13:751-61.

Horn SP, Sanford RL Jr. 1992. Holocene fires in Costa Rica. Biotropica 24:354-61.

Hu FS, Kaufmann D, Yoneji S, Nelson D, Shemesh A, Huang Y, Tian J, Bond G, Clegg B, Brown T. 2003. Cyclic variation and solar forcing of Holocene climate in the Alaskan subarctic. Science 301:1890-3.

Johnson EA. 1992. Fire and Vegetation Dynamics: Studies from the North American Boreal Forest. Cambridge: Cambridge University Press. 129 p.

Johnson EA, Larsen CPS. 1991. Climatically induced change in fire frequency in the southern Canadian Rockies. Ecology 7:194-201.

Johnson EA, Wowchuk DR. 1993. Wildfires in the southern Canadian Rocky Mountains and their relationship to mid-troposphere anomalies. Canadian Journal of Forest Research 23:1213-22.

Johnson EA, Fryer GI, Heathcott MJ. 1990. The influence of man and climate on frequency of fire in the interior wet belt rain forest, British Columbia. Journal of Ecology 78:403-12.

Ketterings QM, Bigham JM. 2000. Soil color as an indicator of slash-and-burn fire severity and soil fertility in Sumatra, Indonesia. Soil Science Society of America Journal 64:1826-33.

Lertzman K, Gavin D, Hallett D, Brubaker L, Lepofsky D, Mathewes R. 2002. Long-term fire regime estimated from soil charcoal in coastal temperate rain forests. Conservation Ecology 6(2), paper 5. Online at http://www.ecologyandsociety.org/vol6/iss2/art5/.

Long CJ, Whitlock C, Bartlein PJ, Millspaugh SH. 1998. A 9000-year fire history from the Oregon Coast Range, based on a high-resolution charcoal study. $\mathrm{Ca}$ nadian Journal of Forest Research 28:774-87.

Lord TM, Green AJ. 1986. Soils of the Fort St. JohnDawson Creek area, British Columbia. Land Resource Research Centre, Agriculture Canada. Report 42. $130 \mathrm{p}$.

Masters AM. 1990. Changes in forest fire frequency in Kootenay National Park, Canadian Rockies. Canadian Journal of Botany 68:1763-7.

Matthews WH. 1980. Retreat of the last ice sheets in northeastern British Columbia and adjacent Alberta. Geological Survey of Canada Bulletin 331:1-21.

McGeehin J, Burr GS, Jull AJT, Reines D, Gosse J, Davis PT, Muhs D. 2001. Comparison of sediment dating 
techniques. Radiocarbon 43(2A):255-61.

Meidinger DV, Pojar JJ. 1991. Ecosystems of British Columbia. Vancouver: B.C. Ministry of Forests Special Report Series 6.330 p.

Meyer GA, Pierce JL. 2003. Climatic controls on fire-induced sediment pulses in Yellowstone National Park and central Idaho: a long-term perspective. Forest Ecology and Management 178:89-104.

Meyer GA, Wells SG, Jull AJT. 1995. Fire and alluvial chronology in Yellowstone National Park: climatic and intrinsic controls on Holocene geomorphic processes. Geological Society of America Bulletin 107: 1211-30.

Meyer GA, Pierce JL, Wood SH, Jull AJT. 2001. Fire, storms and erosional events in the Idaho batholith. $\mathrm{Hy}$ drological Processes 15:3025-38.

Millspaugh SH, Whitlock C, Bartlein PJ. 2000. Variations in fire frequency and climate over the past $17,000 \mathrm{yr}$ in central Yellowstone National Park. Geology 28:211-4.

Molloy BPJ, Burrows CJ, Cox JE, Johnston JA, Wardle P. 1963. Distribution of subfossil forest remains, eastern South Island, New Zealand. New Zealand Journal of Botany 1:68-77.

Pierce J, Meyer G, Jull AJT. 2004. Fire-induced erosion and millennial-scale climate change in northern ponderosa pine forests. Nature 432:87-90.

Reimer PJ, Baillie MGL, Bard E, Bayliss A, Beck JW,
Bertrand CJH, Blackwell PG, Buck CE, Burr GS, Cutler KB, Damon PE, Edwards RL, Fairbanks RG, Friedrich M, Guilderson TP, Hogg AG, Hughen KA, Kromer B, McCormac G, Manning S, Bronk Ramsey C, Reimer RW, Remmele S, Southon JR, Stuiver M, Talamo S, Taylor FW, van der Plicht J, Weyhenmeyer CE. 2004. IntCal04, terrestrial radiocarbon age calibration, 0-26 kyr BP. Radiocarbon 46(3):1029-58.

Sanborn P, Geertsema M, Jull AJT, Hawkes B. 2006. Soil and sedimentary charcoal evidence for Holocene forest fires in an inland temperate rainforest, east-central British Columbia, Canada. The Holocene 16:415-27.

Stuiver M, Reimer PJ, Bard E, Beck JW, Burr GS, Hughen KA, Kromer B, McCormac G, van der Plicht J, Spurk M. 1998. IntCal98 radiocarbon age calibration, 24,000-0 cal BP. Radiocarbon 40(3):1041-83.

Turcq B, Siffedine A, Martin L, Absy ML, Soubies F, Suguio K, Volkmer-Ribeiro C. 1998. Amazonia rainforest fires: a lacustrine record of 7000 years. Ambio 27: 139-42.

White JM, Mathewes RW. 1986. Postglacial vegetation and climatic change in the upper Peace River district, Alberta. Canadian Journal of Botany 64:2305-18.

Whitlock C, Shafer SL, Marlon J. 2003. The role of climate and vegetation change in shaping past and future fire regimes in the northwestern US and the implications for ecosystem management. Forest Ecology and Management 178:5-21. 